\title{
The Subsidized Secondary Education Policy: What are the Socio- Economic and Cultural Implications on Equitable and Quality Education in Madera West District, Mandera County; Kenya?
}

\author{
Mohammed Abdi ADAN ${ }^{1}$, John Aluko ORODHO ${ }^{2}$, \\ Doctorate student in the Department of Educational Management, Policy and Curriculum Studies, School of \\ Education, Kenyatta University, Kenya. \\ Associate Professors, Specialist in Research and Statistics, Department of Educational Management, Policy and \\ Curriculum Studies, School of Education, Kenyatta University, Kenya
}

\begin{abstract}
The gist of this paper was to examine the socio-economic and cultural implications of subsidized secondary education policy on equity and quality education in Mandera West District, Mandera County, Kenya. The study was premised on the Reconstructionist Theory propounded by Brameld and George Counts that emphasizes the need to address social questions and a quest to create a better society and wonderful democracy. Mixed methods involving quantitative and qualitative approaches were used to collect and analyze data from a stratified sample of 126 respondents comprising of headteacher, teachers, members of the Board of Management, and Quality Assurance and Standards Officers (QUASO). The findings revealed mixed results in the sense that although the subsidized secondary education policy was making remarkable impact in terms of accelerated access to education, there was high wastage exhibited in low transition rates from lower to upper classes, low retention rate, widening inequality that was negatively affecting education of the girl-child, and overall low quality of education. The major factors contributing to this scenario were largely socioeconomic and cultural in nature, with poverty, low formal educational attainment of most parents, low premium attached to the education of the girl-child and some retrogressive socio-cultural factors being the most conspicuous. The school based factors compromising equity and quality education included; unfriendly schools especially to the females, overcrowding in classes, high student-teacher ratios, and inadequate and poorly maintained physical and instructional resources. It was concluded that the subsidized secondary education policy was not efficient and effective in providing equitable and quality education. It was recommended that there should be increased campaigns to empower the economic status of communities and reverse their negative attitude towards education, increase funding to schools for the purchase of the critical instructional resources geared towards creating more child friendly schools and enhanced students' academic performance. [300 Words].
\end{abstract}

Key Words: Subsidized secondary education, education policy, socio-economic factors, cultural factors, equity. Quality, Mandera West District, Mandera County, Kenya,

Background to the study

\section{Introduction}

Research studies that attempt to explore the socio-economic and cultural contexts in which free education policies in their respective countries have not been conclusive due to the intertwined nature of the problem (Sava \& Orodho, 2014, Karongo \& Orodho, 2014; Orodho,2013). The best starting point would be to trace the chronology of these policies in Kenya and examine their justification to be able to understand their implications on equitable and quality educational provision (Mwinyipembe \& Orodho, 2014; Njeru \& Orodho, 2003; Orodho, 2014). In 2003, the Government of Kenya, following the 2002 election campaign pledge , introduced the Free Primary Education (FPE) policy in order to universalize access to primary education and increase educational attainment in the country( Oketch \& Ngware,2012, Republic of Kenya, 2005a, 2005b).This policy was followed later with the Free Day secondary Education (FDSE) policy in 2008 which equally was aimed at accelerating enrollment and quality of secondary education in the country( Odhiambo,2010). These policies had international backing and credibility, as these were part of the universally agreed Millennium Development Goals (MDGs), and other internationally agreed protocols (Orodho, 2013). This broad Vision of education and the holistic approach to sector development was fully embraced by Kenya as a critical vehicle for realizing Vision 2030, the road map for development (Odhiambo, 2010; Gikondi et.al, 2010; Republic of Keya/UNESCO, 2012). The Constitution of Kenya 2010 unequivocally promises all Kenyans unprecedented opportunity to capitalize on the progress made thus far in order to exploit the full potential of education for each and every child, youth and adult in the nation (Republic of Kenya, 2010, 2012). In addition, the Basic Education 
Act 2013 reiterates the fact that basic education which has been made free and compulsory in Kenya should be operationalized through the legal framework enshrined in the Act (Republic of Kenya, 2012a). Both the Constitution 2010 and Basic Education Act 2013 guarantees and provides legal mechanisms of ensuring that every Kenyan citizen gets access to basic education and other economic and social rights that hinge upon the citizens access to, and performance in, education, as much as on the application of knowledge, attitude and skills gained through the educational experience( Republic of Kenya, 2010a 2010b, Republic of Kenya/UNESCO, 2012; UNESCO, 2012 ; World Banks, 2012; Republic of Kenya,2013).

The large body of literature on household variables indicate that household characteristics are important determinants of schooling decisions and outcomes (Dryden-Peterson \& Sarah, 2011; Brookings Institute, 2013; Ngware, Oketch, Ezeh, \& Mudenge, 2009; Sava \& Orodho, 2014). The household production function approach developed by Baker ( 1965) is often used to by researchers in economics of education to show that household characteristics such as income and levels of parental education determine whether a child enrolls in school, stays in school, learns and makes progress to higher levels of education ( Oketch \& Ngware,2012). It is also used in economics of education to model other household schooling decisions such as the type of school that a child attends (Kingdom, 2007, Ngware, et.al,. 2012). In Africa, studies that use the household production function approach usually differentiate between rural and urban households. Rural household re often portrayed as disadvantaged in terms of having lower income and lower levels of education and therefore being associated with disadvantaged schooling decisions and outcomes compared with urban areas (Jones, 2005, McMahon, 2005, Mugisha, 2006; Walque, 2005). Studies by Sava and orodho (2014) focusing on socio-economic factors influencing children's access to education in informal settlements and that by Orodho(2013) in Mandera are in agreement that the home-based factors such as the socio-economic and cultural contexts are important variables in understanding the implications of free education policies on quality education( Orodho,2013; Sava\& Orodho,2014). It is against this background that this study made an attempt to assess the socio-economic implications of subsidized secondary education in Mandera West District, Kenya.

\section{The State of the Art Review}

In reviewing the literature on Socio-economic status (SES), it is instructive to conceptualize the term socio-economic as an economic and sociological combined total measure of an individual's, family's or group's economic and social position in relation to others, based on income, education, wealth and occupation (National Center for Education Statistics, 2008; Sava \& Orodho,2014). This should form a smooth linkage with the chronological development of subsidized secondary education (SSE) in Kenya. We commence the review by examining the introduction of SEE in Kenya before examining the socio-economic and cultural contexts.

\section{Introduction of Subsidized Secondary Education (SSE) in Kenya}

As noted, during the 1990s basic education went through various reforms but the un-conducive political and economic conditions at the time were unable to support its growth. Having to depend on limited resources and donor funding, the government experienced difficulties maintaining educational standards. Subsequently the quality of education deteriorated and there was an increase in the numbers of school-age children who were not receiving formal education. Figures for instance show that massive school dropouts were recorded and that out of about one million students who enrolled in standard one in 1993 and in 1998, less than half a million got to standard eight, a trend that has persisted to date (Oketch and Ngware,2012; Orodho, Waweru, Ndichu \& Nthinguri,2013).

According to Mwiria (2009), Kenya's secondary school population enrollment has risen from 30,120 students in 151 schools at the dawn of independence (1963) to 620,000 students in 3,000 schools in the year 2000. Mwiria reported that the target enrollment by the end of 2008 was estimated at 1.4 million students in currently reported 4,478 secondary schools. In 2008, the government introduced plans to offer free Secondary education to all Kenyans. Mwiria observed that with the introduction of Subsidized Secondary Education, enrollment is certain to climb higher.

However, the Subsidized Secondary Education program has also created many problems. With increased enrollment year after year, the infrastructure is stretched to the limit and so is manpower. Overcrowded classrooms due to increased number of children are common issue in many secondary schools and the learning facilities available in many schools are inadequate. The pupils to teacher ratio has grown to such a high rate that it has resulted in a decline in the quality of education, mainly due to reduced interactivity between teachers and the pupils( Orodho,2013).

This situation has sometimes led to desperate and ineffectual attempts by the Kenyan government to hire partially trained or untrained teachers to seal the gap, but it has not bore any fruits. And even though the number of girls enrolling in secondary school increases every day, gender disparity is still a major concern especially in the marginalized communities. The inception of the Subsidized Secondary Education program has seen increased government spending in the sector but schools are still ill-equipped while classrooms are either dilapidated, congested, or both. The worrying scenario for the country's poorest areas is the high costs they still bear in terms of development and boarding related costs. While the government has waived tuition fees and provides textbooks, 
other classroom materials such as exercise books, writing materials and other stationery are still the parent's responsibility. This is because the government is facing budgetary constrains as it tries to strike a balance between funding the all important education sector without compromising on other sectors which also need investment.

In 1998 the World Bank and International Monetary Fund (IMF) made recommendations to restructure public institutions to streamline efficiency. One change the government made was to reduce human resources including a freeze on hiring new teachers by the TSC and this resulted in a significant shortage of teachers. Since 2003, the TSC has been working to retain teachers, and the first full recruitment of about 40,000 was proposed for the 2007 fiscal year. However, the education system still has a shortage of about 60000 primary school teachers (African Path, 2008; Oketch and Rolleston, 2007). Despite a sizable portion the budget being allocated to the education sector, the government still relies on donor-funding.

There are many cultural demands and practices that influence full participation in both the domestic and school environment, as many children are also responsible for domestic chores. Although the initial enrollments have been higher in the last five years, there is still the danger of dropout rates not being fully under control (Oketch and Rolleston, 2007; Oketch \& Ngware, 2012; Orodho, 2013). One positive outcome of FPE, however, has been the significant increase in the number of girls in school. Maintaining the quality of education is a challenge that the government continues to address. With large class sizes and competing resources, parents with financial means pulled their children out of public schools and enrolled them in private schools.

To cope with the pressure arising from the increased primary school graduates, the MoE advised all public secondary schools to expand their capacities to a minimum of three streams. In addition, bursary funds targeted at needy secondary schools students was not explicitly expressed in this year's budget. Despite the allocation of substantial funds earmarked for bursary to needy students, through many grassroots level funds such as Local Authority Transfer Fund (LATF), Constituency Development Fund (CDF), Constituency Bursary Fund (CBF), and these funds may not reach many students given the high per student cost in the delivery of secondary education. PER (2004) notes that the annual per student cost in secondary education estimated at Kshs. 21,800 is too high compared to that in other low-income countries. This is perhaps because majority of the students are enrolled in secondary schools, which offer boarding facilities that tend to push the average cost of secondary education upwards (Institute of Economic Affair ; 2007).

In this year's budget the education bursary fund got an allocation of Ksh.800 million which is customarily channeled through the Ministry of Education. The challenges in this sector include the fact that growth in number of secondary schools has not matched that of primary schools leading to a lot of wastage of primary school graduates. The high cost of secondary education is another challenge and has led to high dropout rates. The pupil text book ratio has been high especially in rural areas and urban slums and the HIV/AIDS pandemic has had negative effect on this sub sector (IEA; 2007) .

For Kenya it would be appropriate to refer to expansion of measures already in place as opposed to new measures. For instance the government made a modest increase in education programmes budgetary allocation in the 2009/2010 budget. This is meant to sustain the FPE programme and subsidized secondary education. More funds will be used for programmes such as Most Vulnerable Children Grants (MVCG), support to early childhood education programmes, Home Grown School Feeding Initiative, Bursary, school infrastructural development. Significant amount of the money in the budget is allocated to devolved funds, mainly in the Constituency Development Fund (CDF). It is therefore anticipated that if spent as per plans, there would be influence on school access and retention. The government hired 10,000 teachers on contract as a short term measure to address acute teacher shortage in primary and secondary schools in the country (Republic of Kenya, 2010). However, the Kenya National Union of Teachers (KNUT; 2010) estimates that Kenya has a shortage of 60,000 teachers. On its part, the government estimates the shortage at 30,000 teachers' countrywide (Republic of Kenya, 2010). The government has expanded funding on Cash Transfer Grants to an annual budget of Kshs 300 million (USD 3.8M). However, the effect of this on education is yet to be ascertained.

\section{Examining Socio-economic Factors in Education}

The government of Kenya recognizes that provision of universal education is an important milestone to economic and social development (Republic of Kenya, 2008). In particular it has been established that by providing primary education to women, a society is able to hasten its development. The government has also increased its budgetary allocation to education as well as introducing a Constituency Bursary Fund for efficient facilitation of education at the grassroots level. Research on poverty by Sava\& Orodho ( 2014) was conducted to determine the progress that has been made in terms of economic development as it relates to education and other socioeconomic amenities. The study revealed that despite the milestones being achieved at the national level, the situation is still worse in some geographic areas of the country (Orodho, 2013)

Kamaara (1999) notes that one of the threats facing youth in developing countries is reproductive health and the data in Kenya indicates that $17 \%$ of girls between age 15 and 19 have at least one child. Kamaara also reports on a national study which found that about $36 \%$ of all pregnant young women aged 15-24 visiting antenatal 
care clinics had a sexually transmitted disease. Health education has since been integrated into the curriculum through subjects such as biology and social ethics (International Bureau of Education, 2004).

UNESCO, UNICEF, and other non-governmental organizations have conducted research aimed at improving female access to education (Buchman, 2000). Buchman (2000) reports that determinants of educational inequality are generally informed by three perspectives: economic, resource constraints, and cultural perspectives. Each of these perspectives has been used to explain educational decision making in developing countries, and each predicts participation in formal schooling. In the case of Kenya, cultural norms and gender stereotypes do hinder girls' participation in school, where typically mathematics and science are seen as 'boys subjects' while home science is a 'girls' subject'. Report by Orodho, Waweru \& Getange (2014) in Mandera indicate that although Kenya has high levels of primary school enrollment, data show that as girls enter secondary school in their teenage years, their enrollment begins to fall compared to that of boys.

The Orodho et.al.,(2014) counsel that educating women influences many socio-cultural and socioeconomic indicators including health care, infant mortality, and reducing population grown. Further, public health studies that link maternal education to health indicate that education is pertinent to national development, and that those inequalities in mortality maybe related to the socioeconomic status of the population. In addition, higher levels of education are inversely related to levels of health and mortality and that the differences in the levels may be partially explained by the social and economic policies (Desai and Alva, 1998; Orodho,et.al.,2014). Health education that specifically focuses on HIV/AIDS education has become a focal point in the government's agenda, and studies are being conducted to evaluate the knowledge, attitudes and sexual behavior with HIV/AIDS school age children (UNICEF, 2008).

Education and Diversity

Regional disparities in education are closely related to, and often compounded by other socioeconomic factors. Beginning in the colonial period some groups, especially the nomadic and pastoralist groups have historically been marginalized, while those groups that had more interaction with the British during the colonial reign were exposed to Western-based education and economic systems earlier. Initially, formal education was linked to Christianity but beginning in the 1970s, the government made accommodations for Muslim students. This was done by acknowledging Madras and religious schools, and later in the 1980s by introducing Hindu and Islamic Religious Education and classes in the curriculum (Alwy \& Schech, 2004; Buchman, 2000). The government and various NGOs are currently working to make accommodations for children from nomadic, pastoralist, and other underrepresented groups by increasing resources, teachers, and building more boarding schools for them.

The prevalence of disability in Kenya is mainly due to limited preventive and rehabilitation services. The government has taken measures to cater for the quality of special education in the country and the MoEST has adopted an integration policy that provides children with special needs, both physical and mental to cater for in regular schools (Republic of Kenya, 2000). According to the MOE, presently, there are 57 primary schools for children with disabilities which enroll a total of 8,000 children. There are an additional 103 integrated units in mainstream primary schools, three high schools for students with physical disabilities, two high schools for students with hearing disabilities, and one high school for students with visual disabilities.

Special Education in the country was further addressed by the implementation of degree courses at Kenyatta University's Faculty of Education. Special Needs Education (SNE) is disseminated through a centralized curriculum (Republic of Kenya, 2008). According to the MOE, some schools have vocational training integrated units in secondary schools and agricultural technical trade schools to cater for learners who are able to physically work in skills and trades areas. Education assessment and resource centers have also been established to provide early intervention services with assessment and appropriate placement. While this approach implies that all students attain the same learning experiences, their special needs can put them at a disadvantage. Subsidized Secondary Education Program has to go beyond its usual jurisdiction to address the challenges of students with special needs and this call for additional resources to provide facilities and resources needed for teaching and learning by special education sector. Hence, the KIE is mandated to develop curriculum, research and develop relevant curriculum, and provide supporting materials for SNE.

The Consortium for Street Children (2002) estimates about 250000 street children in Kenya, with over 60 000 in Nairobi. Many are second or third generation street children while others have more recently been orphaned (Ouma, 2004). UNESCO reports that as a result of the discrimination they suffer, street children and children orphaned by AIDS are more vulnerable than other children as they struggle to survive daily, putting them at a higher health and social risks. Shetty and Powell (2003) also note that children who have lost both parents are more likely to drop out of school than those who have lost one parent. Therefore the Subsidized Secondary Education Program has also to deal with the problem of street and orphaned children many of whom have taken advantage of Free Primary Education to go through their basic education. After sitting the Kenya Certificate of Primary Education Examinations, they either fail to proceed to secondary schools due to lack of school fees or they get enrolled in form one but drop out of secondary schools soon after joining form one. The SSE Program has the mandate to cater for the needs of orphaned and street children through bursary funds and tuition waivers. 
In one study, data indicated that $52 \%$ of children orphaned by AIDS were not in school, compared with $2 \%$ who were not orphaned. Of the orphaned children, $56 \%$ of the girls and $47 \%$ of boys were likely to drop out of school within 12 months of a parent's death. Although the government has put measures in place to enable orphaned children access to SSE, the children still have health and emotional needs, as many of their caretakers who are mostly grandparents do not have the economic means (Nyambedha et al., 2001). Further, the Children's Act passed in 2001 to address the needs of children has not been fully implemented due to limited financial resources and lack of capacity (Republic of Kenya, 2008). The government is however working closely with UNESCO, UNICEF and other NGOs to cater for the children's needs.

\section{Economic Implications of Subsidized Secondary}

Kenya Vision 2030 is the nation's new development blueprint for 2008 to 2030 which aims at making Kenya a newly industrializing, middle income country providing high quality life for all its citizens by the year 2030 (NESCO, 2007). The plan is to be implemented in successive five-year terms with the first plan covering 2008-2012. The education goals of the 2030 Vision are to provide globally competitive quality education and training and research for development. This is to be achieved through reducing literacy by increasing access to education, improving the transition rate from primary to secondary schools, and raising the quality and relevance of education. Other goals are the integration special needs education into learning and training institutions, and increasing the adult literacy rate to $80 \%$. The government also aims to increase the enrollment in schools to $95 \%$ as well as the transition rates to technical colleges and higher education to $8 \%$. In addition, the rate of students joining universities should expand from $4.6 \%$ to $20 \%$ within this period, while simultaneously boosting emphasis on science and technology courses (Lawrence \& Orodho, 2014).

However, it is important to note that the expansion of education requires expansion of teaching-learning resources in order to accommodate the extra numbers joining secondary schools as a result of the SSE program. It is impossible for SSE program to achieve much if the input required for its successful implementation are lacking. This is a gap which was to be addressed by the current study through an audit of the program at the time of the study. It was necessary to establish the required resources for SSE program to operate smoothly and the actual amount available for the program from all the possible sources(Lawrence \& Orodho, 2014).

The government has specified the implementation strategies which include integrating early childhood into primary education, reforming secondary curricula, updating teacher education, and strengthening partnerships with the private sector. In addition, the government has goals to improve special needs programs and adult training program, and to revise the higher education curriculum. Specific educational development projects for 2012 are to increase the number of secondary schools by building 560 new secondary schools, to establish a teachers' recruitment program to employ 28,000 more teachers, to establish a computer supply program that will equip students with modern ICT skills, to build at least one boarding primary school in each constituency in the pastoral districts for nomadic populations, and to roll out the education voucher system program in five districts (Republic of Kenya ( Republic of Kenya,2008).

Vision 2030 also aims to capitalize on knowledge in science, technology and innovation (STI) in order to function more efficiently, improve social welfare, and promote democratic governance. STI is to be applied in all the sectors, and the education and training curricula in the country will thus be modified to ensure that the creation, adoption, adaptation and usage of knowledge becomes part of formal instruction. A new incentive structure will also be developed to support the use of STI in specialized research centers, and universities(Lawrence \& Orodho, 2014). Vision 2030 is an ambitious development plan which commits education system in Kenya to review and restructuring in order to meet the envisioned targets and thus it comes with huge economic implications for the country. Vision 2010 needs the close participation of various stake holders in education sector in the country namely, the Government of Kenya, Development Partners, NGOs and local community members in provision of teaching-learning resources and funding institutional changes needed to align the secondary education system in Kenya towards efficient and quality delivery of teaching-learning experiences to the learners. The current study sought to determine the level of participation of different stakeholders in the new program of SSE in Mandera West District in order to determine the level of conformity with the objectives of vision 2030.

According to The Institute of Economic Affairs (IEA) (2007), there was an urgent need to coordinate the education sector reforms to avoid duplication and wastage of resources and hence the Ministry of Education, Science and Technology (MoEST) developed the Kenya Education Sector Support Program (KESSP). In an Education Position Paper, KESSP is a joint partnership between the MOE and development partners which is used as a framework for mobilizing more resources in the education sector in efforts to accelerate achievement of the overall Education for All (EFA) goals by 2015. According to IEA, KESSP is a sector wide approach to the development of the education sector in Kenya over a period of five years with an aim of eliminating duplication, promoting efficiency in resource use and harmonize/consolidate the recommendations arising from the various education sector reviews undertaken by the MoEST. Therefore an audit of the SSE program in Mandera West District was necessary to fill the informational gap on program achievements in terms of economic and social benefits realized so far through the SSE program. 
The overall National Development objectives of the Government of Kenya are accelerated economic growth and rising productivity of all sectors, equitable distribution of national income, alleviation of poverty through the provision of basic needs, enhanced agricultural productivity, industrialization, accelerated employment creation and improved rural-urban balance. For these goals to be realized all factors and actors of production must be closely coordinated so that they applied optimally (Republic of Kenya, 2006). Particularly, the Ministry of Education under the current education Policy Framework states that the country's education philosophy, vision, mission, goals and objectives are guided by national unity, unity of purpose, social responsibility moral and ethical values, life-long learning, science and technology, equity and the environment.

\section{Statement of the problem}

Despite the introduction of SSE to accelerate access and retention as well as the provision of quality education across the country, the gains have not trickled equitably in most vulnerable communities, including the nomadic pastoralist communities .Thus, the socio-economic implication of SSE to the people of Mandera West District, the Government of Kenya and other stakeholders in the Kenyan education sector is crucial. The success of Free Primary Education Program (FPE) in Kenya which was introduced by the Kibaki Administration in 2003 has led to the introduction of Subsidized Secondary Education for government secondary schools in 2008. In the program, the government remits an equivalent of KShs. 10, 300 per student per year to public secondary schools in Kenya to cater for tuition expenses and parents are only required to pay for accommodation and other development expenses for their children.

The Free Primary Education and Subsidized Secondary Education Programs have increased participation and provided children from the poor strata of the society with an opportunity to continue with their education and help Kenya fight poverty and strive towards achieving its Millennium Development Goals (MDGs). However, the program has come with educational and socioeconomic challenges in implementation and execution (UNESCO, 2008). According to UNESCO (2008), increased enrollment year after year has overstretched schools infrastructure and manpower to maximum limits. Ministry of Education Statistical Booklet ( Republic of Kenya,, 2006a) observed that within the first week of FPE Programme in Kenya, more than 1.3 million new students were registered and many more were streaming in by the day.

In 2008, President Kibaki announced that Kenya had introduced a free secondary schooling education program that targeted raising student enrolment to 1.4 million by the end of the year. The scheme proposed to pay tuition fees for students while parents would still be required to meet boarding school costs and school uniforms. Three years after the Government of Kenya began to implement Subsidized Secondary Education (SSE) programme in public secondary schools, the Kenyan education system is struggling to accommodate the increased demand due to the two programmes. Although, US \$ 41 million was to be released to pay for the first phase of the program (BBC News, 2008), yet, the funding has been inadequate. In many schools, classrooms are overcrowded due to increased number of students and learning facilities are inadequate in almost all schools. The pupils to teacher ratio has grown to such a high rate that it has resulted in a decline in the quality of education (KNUT, 2009).

Thus, the socio-economic implication of SSE to the people of Mandera West District, the Government of Kenya and other stakeholders in the Kenyan education sector is crucial. Hence the focus of this study. This study was therefore meant to help the Kenyan people understand the socio-economic implications of SSE program and help improve the system to make it more responsive to the increased demand for secondary education in Kenya.

\section{Purpose and Objectives of the study}

There has been little assessment of the effectiveness of Subsidized Secondary Education on economic and social development of Mandera West District yet The Government of Kenya spends approximately, Ksh 13,390,000 per year to subsidize secondary education for the 1,300 secondary school students in the District. The purpose of this study was to examine the socio-economic and cultural implications of subsidized secondary education in Mandera West District. Thus, the the overall objective of this study was to determine the socio-economic implication of Subsidized Secondary Education in Mandera West District.

Specifically, the present study sought to explore the following objectives:

(a) To determine the home- based context of subsidized secondary education in Mandera West District.

(b) To establish the school-based context of the subsidized secondary education initiatives in Mandera West District.

(c) To determine the challenges confronting the implementation of SSE in Mandera West District.

\section{Theoretical Underpinnings}

This study was guided by the Classical Liberation Theory of Equal Opportunity and Social Darwinism as proposed by Charles Darwin in an attempt to find out some of the socio-economic factors in the context of subsidized secondary education in Mandera West District, Kenya. According to this theory, an individual's Socio-Economic Status (SES) is a product of environment they live in thus nature and nurture have a bearing on 
an individual's destiny. Equal opportunity is a stipulation that all people should be treated similarly, unhampered by artificial barriers or prejudices except when a particular distinctions can be explicitly justified. Informal settlements are areas that are neglected by the central governments in terms of equal opportunities leading to exclusion in terms of social and economic development and this impact negatively on education. Socio-economic factors such as family income level, parents' level of education, adequacy of learning and teaching materials or resources and occupation, all influence the quality and availability of education as well as the ability of education to improve life circumstances. Low SES and its correlates, such as lower education, poverty, and unemployment, ultimately affect a society as a whole. Inequalities in wealth distribution and quality of life are increasing in the informal settlements. The study therefore attempted the extent to which the Classical Liberal Theory of Equal Opportunity and Social Darwinism can effectively be linked to the implications of subsidized secondary school education in the context of the prevailing socio-economic factors that influence pupils" access to education in pastoralist communities where inequalities of education provisions are severe on equity and deficiency grounds.

\section{Research Design and Methodology}

The study was a mixed method (quantitative and qualitative) designed to investigate the socio-economic implications of subsidized secondary education (SSE) program in Mandera West District of Mandera County. According to Brooks (2013 and Orodho (2012), descriptive research studies are designed to obtain pertinent and precise information concerning the current status of phenomena and whenever possible to draw valid general conclusion from the facts discovered. The design was applicable for a study which sought to establish the social and economic aspects of providing subsidized secondary education to the people of Mandera West District. Orodho (2009a, 2009b 2012) and Brooks (2013) are in agreement that surveys can be used for explaining or exploring the existing status of two or more variables at a given point in time.

Creswell (2009) similarly perceive a descriptive survey design as one that provides an investigator with quantitative and qualitative data. Against this background and as envisaged, descriptive survey provided the study with appropriate procedure for investigating the socio-economic implications of SSE Program in Mandera West District of Mandera County. The study used a random sample of 126 subjects including the teachers, headteachers and members of the Board of Management in schools in the study locale. Questionnaires, which were first piloted to determine their validity and reliability, were used to collect data from the school principals. Interviews and focus group discussions were used to collect data from teachers and BOM members, respectively. Quantitative data from questionnaires was analyzed using the s Statistical Package for Social Sciences (SPSS) Computer programme version 20 (Orodho, 2009b). The qualitative data from interviews and fgds were transcripted and analyzed thematically (Orodho, 2012).

\section{Findings And Discussions}

\section{The home based Context of the learners}

The findings of the study showed that, a majority of the sampled students had both parents while a good number were total orphans or children of single mothers which implies that there is high dependency on government funded SSE programme by many students from the District of study. Furthermore, the study established that majority constituting slightly over half of male parents from the District are pastoralists with a small number constituting just one quarter of the total were found to be owning small scale businesses while majority ( $80.9 \%)$ of female parents are housewives with a negligible number (10.6\%) owning small scale businesses. This implies that parents from the District have low economic power and therefore depend entirely on government funded SSE programme to educate their children. The study also revealed that majority of students in the District had their brothers and sisters in other public secondary schools in the District and are therefore multiple beneficiaries of the programme.

The findings of the study showed that, a majority, constituting nearly half of the sampled respondents had primary education, followed by secondary education (16.3\%) and a few $(2.1 \%)$ had no formal education which is grossly inadequate for a meaningful socio-economic development of the community under study. The results also revealed that a small majority (40.8\%) of parents had one child in secondary school, closely followed by parents with two children making one third of the total and those with four children or more. Furthermore, the study found out that a majority of the parents had students in form one, followed closely by parents with students in form two, form three and form four in descending order showing that SSE Programme has increased level of enrolment in public secondary schools in the District.

The findings of this study relating increase in schooling with high levels of parental education is in agreement with the findings of Orodho (2013) who reported that better educated parents appreciate the value of education more than illiterate ones and this plays a significant role in access to and retention of children in education. This study revealed that educated parents are able to assist their children progress in education both 
materially and personal involvement. The study showed that those children whose parents had received formal education enrolled more children in school than those whose parents had not gone to school at all.

The study also revealed that a majority $(60 \%)$ of the parents have low incomes which may not support the cost of educating their children in various public secondary schools in the District. The study established that parents pay an average school fee of KSHS 15,000-17,000 per child per year as an input to the SSE Programme. However, the study revealed that a majority of parents can only afford to pay half or less than half of the amount of school fees charged per year. The study also found out that parents provide school uniforms and games skits, pocket money, meals and beddings for their children.

This is in agreement with literature on cost-sharing as introduced in the 1980s under which the government's task was to recruit and pay the teachers, while parents were responsible for constructing buildings and providing educational resources. A study by Nyangia and Orodho (2014) on cost-saving measures in public secondary schools in Kisumu West District revealed that despite SSE, the cost of education had not decreased substantially for most poor parents. The study by Nyangia and Orodho thus suggested that the amount of capitation per student should be increased alongside individual schools engaging in income generating activities. Similarly, African Path (2007) observed that cost sharing did not work previously because in most areas, parents were financially crippled; the study has also established that many parents in the study area were unable to pay for the school fees charged in schools. These sentiments are also in tandem with those of orodho, Waweru and Getange while studying the strategies that should be used to dismantle the gender jinx in Mandera County, Kenya. The study established that home based factors, especially the retrogressive socio-cultural practices should be addressed in attempts to develop education in Mandera District.

\section{The School based context}

The study found out that School Board Members contribute to the implementation of Subsidized Secondary Education programme by ensure that resources are used for the right purpose only and according to the head count; sourcing for financial support, monitor and evaluate school development projects; and approve budgets, identify and allocate resources for specific projects and oversee school spending. The study established that the Government of Kenya and other stake holders provide resources to support SSE programmes through periodic disbursement of SSE programme funds directly to public secondary schools, Constituency Development Funds managed by local MPs, and sponsorship funds provided by some Faith Based and Non-Governmental Organizations operating in the District.

The study established that SSE programme has enabled many students in the District to continue with their secondary education despite the fact that majority of them have huge fee balances which accumulated over time. The study also revealed that through SSE programme, students are provided with textbooks and other learning materials, examination materials and other related costs, meals and accommodations. The study established that an overwhelming majority of students and parents are satisfied with SSE programme in Mandera West District as it assists many needy students continue with school and has reduced school dropout rates in the District. Overall, SSE programme has economically empowered parents in Mandera West District through subsidized fees payable to public secondary schools. However, for the gains to be translated into students retention, the strategies to create chilfriendly schools should be intensified ( Orodho, Waweru \& Getange,2014).

\section{Challenges during implementation of subsidized Education Policy}

The study further established that despite immense progress reported after the implementation of Subsidized Secondary Education Programme in Mandera West District, there are some challenges that are still being experienced. Among the challenges identified include: non participatory decision making process involving the expenditure of schools funds; increased enrolment of students which results in overcrowding and congestion; shortage of teachers to handle increased student enrolment; dropping standards of education schools; in adequate facilities due to inadequate funds; high expectation by the community; and corruption and misappropriation of school funds.

This finding is consistent with that of Orodho (2013) ) and Syombua (2007) who found out that family's income level actually influences pupils' access to education. That the demand for education was governed by a number of socio-economic factors within the family which included occupation and income levels.

\section{Conclusions And Recommendations}

\section{The home based Context of the learners}

The findings of the study lead us to conclude that most of the students in the study locale originate from home contexts characterized with poverty. Some students were also from orphaned backgrounds, hence placing a high dependency on government funded SSE programme by many students from the District of study. Furthermore, the students are largely from nomadic pastoralist background study established that majority constituting slightly over half of male parents from the District are pastoralists with a small number constituting just one quarter of the total were found to be owning small scale businesses while majority (80.9\%) of female parents are housewives with 
a negligible number $(10.6 \%)$ owning small scale businesses. This implies that parents from the District have low economic power and therefore depend entirely on government funded SSE programme to educate their children. The study also revealed that majority of students in the District had their brothers and sisters in other public secondary schools in the District and are therefore multiple beneficiaries of the programme.

It is concluded that educated parents are able to assist their children progress in education both materially and personal involvement. The study showed that those children whose parents had received formal education enrolled more children in school than those whose parents had not gone to school at all.

The study also revealed that a majority constituting nearly two thirds of the parents have low incomes which may not support the cost of educating their children in various public secondary schools in the District. The study established that parents pay an average school fee of KSHS 15,000-17,000 per child per year as an input to the SSE Programme. However, the study revealed that a majority of parents can only afford to pay half or less than half of the amount of school fees charged per year. The study also found out that parents provide school uniforms and games skits, pocket money, meals and beddings for their children. Thus, it was concluded that home based factors, especially the retrogressive socio-cultural practices, should be addressed in attempts to develop education in the context of SSE in Mandera District.

\section{The School based context}

The study found out that School Board Members contribute to the implementation of Subsidized Secondary Education programme by ensure that resources are used for the right purpose only and according to the head count; sourcing for financial support, monitor and evaluate school development projects; and approve budgets, identify and allocate resources for specific projects and oversee school spending. The study established that the Government of Kenya and other stake holders provide resources to support SSE programmes through periodic disbursement of SSE programme funds directly to public secondary schools, Constituency Development Funds managed by local MPs, and sponsorship funds provided by some Faith Based and Non-Governmental Organizations operating in the District.

The study established that an overwhelming majority of students and parents are satisfied with SSE programme in Mandera West District as it assists many needy students continue with school and has reduced school dropout rates in the District. Overall, SSE programme has economically empowered parents in Mandera West District through subsidized fees payable to public secondary schools. However, for the gains to be translated into students retention, the strategies to create chil-friendly schools should be intensified ( Orodho, Waweru \& Getange,2014).

\section{Challenges during implementation of subsidized Education Policy}

With regards to the challenges experienced while implementing subsidized secondary education, it was concluded that despite immense progress reported after the implementation of Subsidized Secondary Education Programme in Mandera West District, there are some challenges that are still being experienced. Among the challenges identified include: non participatory decision making process involving the expenditure of schools funds; increased enrolment of students which results in overcrowding and congestion; shortage of teachers to handle increased student enrolment; dropping standards of education schools; in adequate facilities due to inadequate funds; high expectation by the community; and corruption and misappropriation of school funds.

On the basis of the findings of this study, discussions and conclusions, the following recommendations are suggested if SSE Programme in Mandera West District is to be used as means of further improving the overall social and economic development of the District in particular and other ASAL districts in Kenya. The specific recommendations are:

1. Since it was established that parents from the District have low economic power and therefore depend entirely on government funded SSE programme to educate their children, it is recommended that most community members should be empowered economically by being encouraged to engage in income generating activities.

2. It was evident that educated parents are able to assist their children progress in education both materially and personal involvement. The study showed that those children whose parents had received formal education enrolled more children in school than those whose parents had not gone to school at all. Thus, it is recommended that public campaigns to enlighten members of the community on the value of education should be intensified in the district.

3. The study established that the Government of Kenya and other stake holders provide resources to support SSE programmes through periodic disbursement of SSE programme funds directly to public secondary schools, Constituency Development Funds managed by local MPs, and sponsorship funds provided by some Faith Based and Non-Governmental Organizations operating in the District. It is thus recommended that these innovative efforts should continue and be intensified in order to enhance equitable and quality education in the study locale.

4. Since the study established that there were challenges identified which included:

i. non participatory decision making process involving the expenditure of schools funds; communities should be meaningfully be involved in decision making process in schools. 
ii. increased enrolment of students which results in overcrowding and congestion, it is recommended that communities through parents Teachers Associations (PTA) should be encouraged to supplement these facilities;

iii. Shortage of teachers to handle increased student enrolment, the relevant Semi Autonomous Authorities such as Teachers Service Commission should increase and balance the deployment of teaching staff.

iv. Since there was dropping standards of education in schools displayed by poor students' academic performance in the district in national examinations, the Department of Quality Assurance and Standards should be empowered to take appropriate corrective measures.

v. Due to the pronounced inadequacy facilities due to inadequate funding and high expectation by the community to get all assistance from the Government of Kenya, and corruption and misappropriation of school funds, it is recommended that Government subsidy should be increased. The schools should use the few available facilities more effectively. School principals should demonstrate high transparency and accountability of funds.

\section{References}

[1]. African Path (2009). Free Primary Education in Kenya: One of Kibaki's Trump Cards? April 11 2007. African Path, Retrieved March 19, 2009 from http://www.africanpath.com/p_blogEntry.cfm?blogEntryID=584

[2]. Alwy, A. \& Schech, S. (2004). Ethnic Inequalities in Education in Kenya. International Education Journal 5(2), $266-274$.

[3]. Buchman, C. (2000). Family Structure, Parental Perceptions, and Child Labor in Kenya: What Factors Determine who is Enrolled in School. Social Forces 78 (4), 1349-1378.

[4]. Bunyi, G. (2006). Real Options for Literacy Policy and Practice in Kenya [Electronic Version]. Retrieved March 4 2008, from http://unesdoc.unesco.org/images/0014/001459/145956e.pdf

[5]. Desai, S. \& Alva, S. (1998). Maternal Education and Child Health: Is There a Strong Causal Relationship. Demography, 35 (1), $71-81$.

[6]. Becker, G.S. (1965). A Theory of Allocation of Time: Economics, Journal 75 (299), 493-517.

[7]. Brook,.S.E (2013).Selecting a sample. Educational Research, 250

[8]. Brookings Institutions. (2013).Towards universal learning: What every child should learn. Brooks. Brunner, J.S.(1961).The Act of Discovery. Harvard Educational Review, Vol . No. 31 1961.

[9]. Institute of Economic Affairs (IEA) (February, 2007). Engendering Education Sector Budget: Reforming Future Education Sector Budgets. The Institute of Economic Affairs (IEA): Nairobi, Kenya.

[10]. Kunst, A. E. \& Mackenbach, J. P. (1994). The size of mortality differences associated with educational level in nine industrialized countries. American Journal of Public Health, 84 (6), 932-937.

[11]. Lloyd, C. B., Mensch, B. S., \& Clark, W. H. (2000). The effects of primary school quality on school dropout among Kenyan girls and boys. Comparative Education Review, 44 (2), 113-147.

[12]. Kamaara, E. (1999). Reproductive and sexual health problems of adolescent girls in Kenya: A challenge to the church. Reproductive Health Matters, 7 (14), 130-133.

[13]. Kingdom, G.G (2007).The progress of school education in India.( Working Paper No.WPS-071). Retrieved from in November22,2013 from : http://www.gprg/pubs/workingpapers/pdfs

[14]. MOE,(2006). 'Education monitoring information system (EMIS). 'Ministry of Education, Government of Kenya: Ministry of Education

[15]. National Center for Educational Statistics (31 ${ }^{\text {st }}$ March, 2008). Available at http;//nce.ed.g or /programs/coe/glossary/s.asp

[16]. Ngware,M.,Ezeh,E., Oketch ,M.,Mudenge,N.(2009). Do household characteristics matter in schooling decisions in Kenya? Equal Opportunities International 28 (7) 591-608.

[17]. Njeru H. N \& Orodho A.J (2003). Access and participation in secondary School Education in Kenya: Emerging Issues and Policy Implications, IPAR Discussion paper NO. 037/2003 ISBN 9966-948-27-9.

[18]. Nyangia,E.O \& Orodho, A.J.(2014). Cost-saving measures in public secondary schools : Are these strategies making education affordable in Kisumu West District, Kisumu County, Kenya. Journal of Education and Practice. pp 76-87.www.iiste.org .

[19]. Oketch,M. \&Ngware ,M.W (eds.) (2012).urbanization and Education in East n Africa: African Population and Health Research Center. ISBN 978-9966-21-175-0.

[20]. Orodho, J.A. (2009). Essentials of educational and social science research methods. Nairobi: Masola Publishers.

[21]. Orodho, J .A. (2012). Techniques of writing research proposals and reports in education and social sciences. Maseno/Nairobi: KANEZJA HP ENTERPRISES

[22]. Orodho, J .A. (2013).Progress towards attainment of Education for All (EFA) among nomadic pastoralists : Do home-based variables make a difference in Kenya?.Research on Humanities and social sciences pages 54-67..www.iiste.org.

[23]. Orodho, A.J.,Waweru, P.N., Getange.K.N.(2014). Progress towards attainment of Education For All (EFA) among nomadic pastoralists : How do we dismantle the gender Differential jinx in Mandera County, Kenya?. International Organization of Scientific Research (IOSR) Journal of Humanities and Social Sciences (IOSR-JHSS). Vol.19, Isssue 2, Ver II ( February, 2014). Pp106-117.www.iosrjournals.org

[24]. Syombua, M. J. (2007). The socio-economic factors influencing children's access to and participation in secondary education in Kitui District. MED Unpublished Thesis, Kenyatta University

[25]. Republic of Kenya. (2005a).) Sessional Paper No. 1 on Policy Reforms for Education, Training and Research: Meeting the Challenges of Education Training and Research in the $21^{\text {st }}$ Century. Ministry of Education, Science and Technology (MOEST Nairobi: MOEST.

[26]. - ---------.(2005b). Kenya Education Sector Support Programme 2005 - 2010: Delivering Quality Education and Training to All Kenyans. Nairobi: MOEST.

[27]. (2001): Children's Act, Government Printer, Nairobi

[28]. ------- (2005a) Economic Survey. Government Printers Nairobi

[29]. - --a-- (2005b) Kenya Education Sector Support Programme (KESSP). Government. Printers .

[30]. - -------(2007a). Gender and Education Policy in Kenya. Government Printer. Nairobi.

[31]. -------(2007b).Harmonization of the Legal framework on Education Training and Research: A Report of the task force on review and harmonization of the legal framework on education, training and research. 
The Subsidized Secondary Education Policy: What are the Socio- Economic and ...

[32].

[33].

[34]. ------(2009b).Policy Framework on Nomadic Education in Kenya. Ministry of Education and UNICEF. Nairobi.

[35]. ----.(2010a). The Constitution of Kenya 2010. The Attorney General. Nairobi.

[36]. ------(2010b).Child friendly Schools Manual. Ministry of Education. Nairobi.

[37]. ------(2012a).Sessional Paper No.14 of 2012 on realigning education and training to the Constitution of Kenya 2010 and Vision 2030 and beyond. Ministry of Education Science and Technology. Nairobi. Kenya.

[38]. ------(2012b).A Policy Framework for re-aligning education to the Constitution 2010 and Vision 2030 and beyond.

[39]. -----(2013). The Basic Education Act 2013 No.14 0f 2013. Nairobi.

[40]. Republic of Kenya/UNICEF( 2012).Education for All (EFA) End of Decade Assessment (2001-2010). Ministry Of Education and INICEF. Nairobi.

[41]. Sibanda,S.(2004). Who gets to drop out of school in South Africa? The role of individual and household attributes. African Population Studies. 19(1), 99-117.

[42]. UNESCO (2004a).Monitoring Report 2005 through the UNESCO International Bureau of Education, Geneva. Andersen, L. W. (2004). Increasing Teacher Effectiveness. 2nd ed. Paris, UNESCO International Institute for Educational Planning.

[43]. - - - Challenges of Implementing Free Primary Education in Kenya: Assessment Report

[44]. ------ (2005a): EFA Global Monitoring Report 2005: Education for A1l, The Quality Imperative, UNESCO, Paris

[45]. UNESCO. (2005b). Education For All (EFA) Global Monitoring Report. UNESCO, Paris. United Nations (UN). (2004). Millennium development goals: Progress report 2004. Available at www.un.org/millenniumgoals/mdg2004chart.pdf. Retrieved January $25^{\text {th }} 2010$.

[46]. - ---------(2006) Education for All Global Monitoring Report : Literacy for life. Paris.

[47]. - ------(2010). Education for All Global Monitoring Report: Reaching the Marginalized. Paris.

[48]. -------(2011).Conceptual evaluation and policy development in lifelong learning. Hamburg .UNESCO. Institute of Lifelong Learning.

[49]. ------(2012). Systematic monitoring of education for All. Paris: United Nations Educational, Scientific and Cultural Organization,( UNESCO).

[50]. United Nations .(2012). Youth and Skills: Putting Education to work. EFA Monitoring Report

[51]. -------(2013). A New Global Partnership: Eradicating Poverty and Transform Economy through Sustainable Development. The Report of the High-Level Panel of Eminent Persons on the Post- 2015 Development Agenda. The United Nations

[52]. Uwezo, (2010). Kenya National Learning Assessment Report. Nairobi: Uwezo Accessed on $28^{\text {th }}$ September

[53]. World Bank. (2008). National Assessment of Education Achievement Vol.1 : Assessing indicators of achievement. Washington D.C.

[54]. -------(2010).World Development Indicators. Retrieved Nov.2010 from http://www.publications.worldbank.org.

[55]. ---------(2012).Gender Equity and Development. World Development Reports. Washington D,C. Wright, S. P., Horn, S. P., Sanders, W. L. (1997). Teacher and Classroom Context. Personnel Evaluation in Education, Vol. 11: 57-7. 